\section{Exports restricted}

The new nuclear policy announced by $\mathrm{Mr}$ Jamieson just before Christmas means that Canada will restrict its exports of nuclear equipment and materials to countries that either have signed and ratified the Nuclear NonProliferation Treaty or have "fullscope" nuclear safeguards. In addition, these countries will have to accept the kinds of additional bilateral safeguards announced by Canada two years ago. The alternative to adherence to the NPT means that a country must accept equivalent international safeguards on its complete nuclear programme (outside military aspects if it has nuclear weapons already). This is what Pakis$\tan$ refused to do.

Announcing the policy at a press conference, $\mathrm{Mr}$ Jamieson claimed that Canada now has the toughest requirements imposed by any nation supplying nuclear materials. He said Canada decided on the policy only after it had failed to persuade other members of the so-called London Club to take similar steps together. Canada now hopes that these other nuclearsupplying courtries will follow its lead, which is designed to prevent the proliferation of nuclear weapons. And he suggested that recent tightening of policies by the United States and France was a hopeful sign.
Canada's new policy is seen also as a reinforcement of a safeguards policy announced two years ago, which some uranium customers have not been observing closely. A number of countries, including Japan, Switzerland and the FEC countries, have not yet completed all the required safeguards. After allowing two six-month extensions of supplies, the Canadian government has announced that it will cease uranium shipments at the end of December, 1977, to force compliance with the policy. Mr Jamieson said he hoped that by that time the safeguards would be in place and supplies could continue uninterrupted.

In notes distributed before his press conference, Mr Jamieson said.

Nuclear export policy already requires binding assurances that what Canada provides will not be used for explosive purposes. Existing policy, however, does not cover what a country receives from other suppliers or what it might do on its own. The new policy will close this gap. We will have, therefore, assurance by treaty that Canada's nuclear customers will have been selected from amongst those countries which have made a clear and unequivocal commitment to the non-proliferation of nuclear weapons.

$\mathrm{Mr}$ Jamieson added that Canada recognises the legitimate energy requirements of its trading partners, but is determined to do all it can to avoid

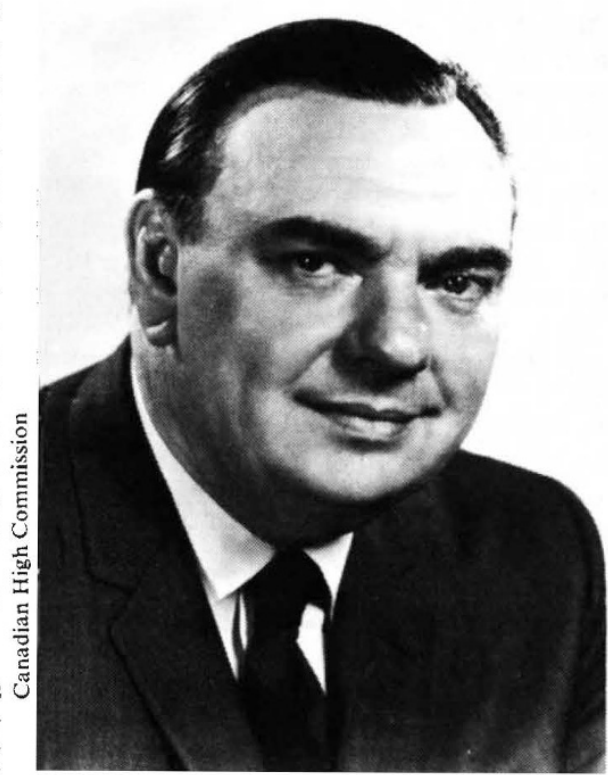

Don Jamieson, External Affairs Minister

contributing to nuclear weapons proliferation. It was for that reason that Canada had unilaterally decided to strengthen further her safeguards requirements. As in the past, "We are prepared to accept the commercial consequences of being clearly ahead of other suppliers. This is the price we are prepared to pay to curb the threat to mankind of nuclear proliferation." $\square$

\title{
Holland's nuclear problems
}

\section{Casper Schuuring reviews a troubled year for nuclear power in the Netherlands}

$I^{\mathrm{F}}$ $F$ it had not been so before, nuclear energy became a major political topic in the Netherlands in 1976. The issue was alive as early as January when debates on the subject led to a government decision to postpone definite planning for three 1,000 MW nuclear power plants until after the next elections in May 1977. The Netherlands already has two existing smaller plants, of $447 \mathrm{MW}$ and $54 \mathrm{MW}$.

Overcapacity in generating power and uncertainties regarding the nuclear fuel cycle were among the main reasons for the move, but political factors were important too. The small Radical Party (PPR), which takes part in the country's coalition government with Labour and Christian Democrats, has two ministers and an under-minister very much opposed to nuclear energy -one of whom is Fokele Trip, the Minister for Science Policy.

Labour, too, has doubts about nuclear power. The Christian Democrats are less perplexed. One of their ministers, for Economic Affairs, had planned the three nuclear plants in his energy memorandum of September 1974. Construction of the first was to start in 1976. Following the government decision to postpone the building of the plants, a declaration signed by 1,200 scientists covering a range of disciplines expressed their concern at the rapid expansion proposed for nuclear energy - as 2,300 colleagues of theirs had done earlier in the United States. Published at the end of January and originally addressed to the government, the declaration was then directed to parliament, which was to discuss the memorandum in February. With the decision on additional nuclear plants pushed to the next government, however, the parliamentary discussions lacked excitement.

\section{Calm doesn't last}

The calm was not to last. A conflict soon arose over a credit guarantee to be given by the government for the building and selling of components for two power plants in South Africa. The work was to be done by a group of industries participating in a consortium together with American and Swiss industries. The government had already indicated in mid-1975 that an export licence would be given, but in parliament a vote of censure was just passed covering exports of nuclear material and equipment to countries that had not signed the nuclear NonProliferation Treaty. South Africa is such a country.

The consortium was originally to have built two reactor vessels; but with a change in arrangements the vessels were to be built by General Electric and the Dutch industries could still take part in the work, for which only an export guarantee was then necessary. Discussion went on so long that at the end of May the deadline passed and a French consortium won the South African order. The Dutch government itself just survived a long and critical period, and relations between government and industry sustained a good deal of damage.

During the summer the Steering Group for Energy Research issued its second report. This concluded that conservation of energy should form a considerable part of Dutch policy, and 
offered two scenarios for energy use over the next 25 years. One involved a continuing growth of $4 \frac{1}{2} \%$ until the year 2000 , and the other a levelling off to zero growth around 1995. The latter scenario, which the Group itself backed, still involved building 6,500 MW of nuclear plant in 2000; the government and electricity producers were planning between 10,000 and $14,000 \mathrm{MW}$ at that time (Holland now has a total generating capacity of $14,000 \mathrm{MW}$ and plans $39,000-56,000 \mathrm{MW}$ by 2000 ). The nuclear research centre was meanwhile transformed into a general energy research institute, incorporating work on wind, fusion and flywheel programmes; a national programme on solar research is foreshadowed for early this year.

\section{Breeder intention}

By last autumn the Economic Affairs Minister $\mathrm{Mr}$ Lubbers was informing parliament almost casually of the intention of provincial and local electricity producers to take part in Superphenix, France's first commercial fast breeder. Some time before, the minister had shown some antipathy towards continued Dutch cooperation with Belgium and Germany-the three countries are building the $300 \mathrm{MW}$ SNR-1 in Kalkar and are each carrying out a part of the research.

In a letter to parliament at the end of August the minister confirmed that the Netherlands was in principle continuing with the Kalkar prolect until SNR-1 was finished, and that Belgium and Germany had agreed to make a decision on a commercial breeder (SNR-2) then. He added that the electricity producers were involved in the SNR project, and were also in the larger European group which will develop the breeder concept further. This group, he said, would proceed with the building of the 1,240 MW Superphenix, which is based on the Phénix, before the SNR-2; as a decision to build this would be taken in the beginning of October, the electricity producers had to decide on their role.

An urgent debate was held in parliament, mainly because the Radical and Labour parties thought the Netherlands would become involved in the commercial development of a breeder before some problems were solved and vital experience was gained. As a result of one of the votes in parliament, Dutch participation is only acceptable once very strict conditions are made regarding safety aspects and international control of the project. The electricity producers agreed, and accepted the maximum financial contribution imposed on the 4,000-million guilders project, though not without some disagreement amongst themselves. By the end of the year, however, no decision to build the breeder had been taken.

\section{Fourth time}

When another nuclear subject attracted attention in October, it was for the fourth time in the year, and in this case created a problem lasting until close to Christmas. The problem concerned uranium enrichment using the gas centrifuge technique, and a definite solution is not actually expected before the end of February. The Anglo-DutchGerman group known as Urenco has pilot plants in Capenhurst in Britain and Almelo in Holland, and partly finished demonstration plants. The difficulty is that a decision is due on extensions to increase Almelo's capacity to 1,200 tonnes. Towards 1987 a further expansion for Urenco to $6,000-8,000$ tonnes is foreseen, and the consortium has definite orders for 2,000 tonnes enriched uranium a year from 1983.

The Radicals are firmly against an expansion of the enrichment capacity for reasons connected with proliferation. There are also commercial objections, and these come not only from the PPR. Mr Lubbers has given confidential information to the parliamentary commissions for foreign, economic and nuclear affairs, but there is hesitation and doubts remain over both proliferation and the possibility of a costly overcapacity in the international enrichment market. The German-Brazilian deal is seen as particularly worrying. The Reflection Group on Energy Policy-active in 1975 before the decision on the three power plants was made - wrote a memorandum on the issue, and the PPR's own group of consultants published a report.

At the same time as all this happened the announcements from the
USA and France of restrictions on nuclear exports became known, as did details of the resistance in Germany to a rapid expansion in the number of nuclear power plants. A further important point was that large commercial concerns like Shell, Philips and DSM, originally involved in the project, did not like to invest more money in it for both economic and political reasons. They believe it is impossible to work when political aspects play such a great role in decision-making.

\section{State of crisis}

A state of crisis existed for several weeks in The Hague, but the cabinet finally decided to agree provisionally to participate in Urenco's expansion, which also involves the Capenhurst plant. The parliamentary committees were informed, but it is still not clear what precisely the Dutch ministers of economic and foreign affairs will discuss with their British and German colleagues on the matter. The decision could mean domestic political problems. The Radicals are still against the idea and could conceivably leave the government. Labour and the Christian Democrats, however, are not willing to export enriched uranium to countries which have not signed the NPT. Each member of the tripartite consortium has the right of veto according to the Treaty of Almelo of 1970, and in Holland the tendency now seems to be to have this exercised not only over the export of uranium but on all nuclear exports.

At the very least, whether this government breaks up over the issue or not, the nuclear power debate will prove important in the formation of the next government. Developments during 1976 have seen to that.

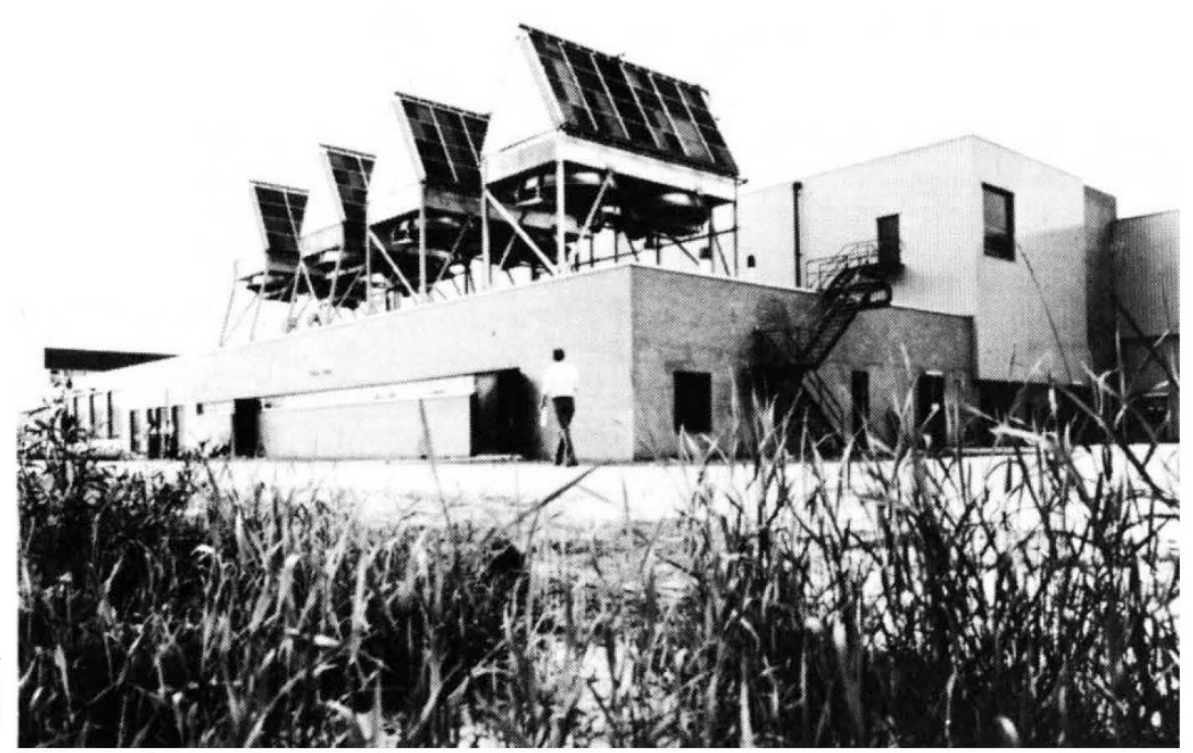

Urenco's plant at Almelo, Holland 